\title{
In nucleo enzymatic assays for the identification and characterization of histone modifying activities
}

\author{
Wolfgang Fischle * \\ Laboratory of Chromatin Biology, The Rockefeller University, 1230 York Avenue, New York, NY 10021, USA \\ Accepted 30 March 2005 \\ Available online 8 August 2005
}

\begin{abstract}
The impact of histone phosphorylation, acetylation, and methylation onto transcription and various other cellular DNA-mediated processes is now well established. Numerous histone modification marks, specific sites carrying particular post-translational modifications, have been described and analyzed in detail. Whereas, many methods for the study of histone post-translational modifications involve sophisticated equipment and techniques, we describe the revival of a very simple procedure for the analysis of histone modifications and histone modifying enzymes, which is derived from experiments first carried out several decades ago. This method is based on the isolation of cell nuclei containing intact chromatin structures that are then incubated with defined enzymatic substrates of histone modifying enzymes. We provide quick protocols for the isolation of nuclei from yeast and mammalian cells and give basic procedures for the phosphorylation, acetylation, and methylation of histones (and other proteins) using these subcellular sources that can be carried out in any laboratory. Simple methods for the analysis of histone modifications using these assays are discussed.
\end{abstract}

(C) 2005 Elsevier Inc. All rights reserved.

Keywords: Histone modification; Phosphorylation; Acetylation; Methylation; Chromatin; Nucleosome; ATP; Acetyl-CoA; S-Adenosylmethionine

\section{Introduction}

Dynamic changes in the local and global organization of chromatin are emerging as key regulators of genomic function. Indeed, post-translational modifications of histones, the main protein component of chromatin, have become of great biological interest. Histones function as acceptors for a variety of post-translational modifications, including acetylation, methylation and ubiquitination of lysine $(\mathrm{K})$ residues, phosphorylation of serine (S) and threonine (T) residues, and methylation of arginine (R) residues. Correlations between specific histone modifications and several biological processes have become evident, and to date, numerous post-trans-

\footnotetext{
${ }^{*}$ Fax: +1 2123277849.

E-mail address: fischlw@rockefeller.edu.
}

lational modification marks of histones have been analyzed in detail $[1,2]$.

Generally, the study of post-translational histone modification can be divided into in vivo experimentation and in vitro analyses. The in vivo approaches make use of classical metabolic isotope labeling techniques for the study and identification of histone marks [3]. More recently, proteomic mass spectrometry-driven approaches have also been deployed, which aided in the discovery of a large number of novel modification marks [4,5]. In vivo studies of histone modification marks have benefited tremendously form the development of modification mark specific antibodies, which have become available for multiple types of modifications and sites [6,7]. In vitro experiments, in contrast, rely on purified or recombinant components of enzyme systems that modify histones governing the addition or removal of modification marks as well as the availability of defined enzyme substrates [8]. 
Historically, histone modifications were first discovered and analyzed in cell free "in nucleo" systems [912]. Whereas, these simple experimental approaches have been forgotten for a long time, they can still be quite useful in the study of histone modifications and modifying activities [13]. They can supplement the in vivo and in vitro methods and partially overcome some of the limitations of purely in vivo and in vitro approaches. In nucleo experiments have been revived and refined in our laboratory as they allow for the analysis of histone modification in a native chromatin context while being easily accessible and fast - especially when combined with modern analytical techniques.

\section{The method}

The extremely simple outline of in nucleo experiments is summarized in Fig. 1. Nuclei can be prepared from various eukaryotic cell types, originating from different organisms, at distinct cellular stages (i.e., cell differentiation, cell cycle, etc.), and after various physiological and non-physiological stimuli (i.e., transduced cells, transfected cells, ionized cells, cells with induced DNA breaks, etc.). Isolated nuclei are incubated with (typically) isotopically labeled substrates donating activated phosphate(ATP), acetyl-(acetyl-CoA), or methyl-( $S$-adenosylmethionine) groups. Modification of histones (and other proteins) can then be qualitatively analyzed by one- or two-dimensional gel electrophoresis combined with autoradiography. Due to their abundance and extremely basic nature, histones can easily be enriched from the nuclei by acid extraction. Usually, histones recovered after acid extraction and gel electrophoresis are sufficiently pure for further analysis. (i.e., mass spectrometry, Edman degradation). For example, quantitative analysis of modification of a certain site can be achieved by a combination of Edman degradation and scintillation counting [13]. Highly pure histones of different subtypes can be prepared by HPLC reversed phase chromatography of the acid extracts on C4 or C8-resins [14]. Indeed, we have used the in nucleo labeling method to prepare defined substrates for the study of histone de-modifying enzymatic activities (i.e., phosphatases, deacetylases, demethylases; for example see Fig. 2).

\subsection{Isolation of cell nuclei}

Detailed, but simple and fast protocols for the isolation of nuclei from yeast and mammalian cells-major sources of study in our laboratory - are provided. Methods for the isolation of nuclei from other sources can be found in the general literature (see for example [15]).

Notes: Inhibitors of proteases and phosphatases or deacetylases are added to various buffers used in the following protocols.

Protease inhibitors: Complete (Roche), or similar broad band inhibitor cocktails (SIGMA); alternatively, the following combination of inhibitors can be used: $20 \mu \mathrm{g} / \mathrm{ml}$ chymostatin (Roche; stock, $20 \mathrm{mg} / \mathrm{ml}$ in

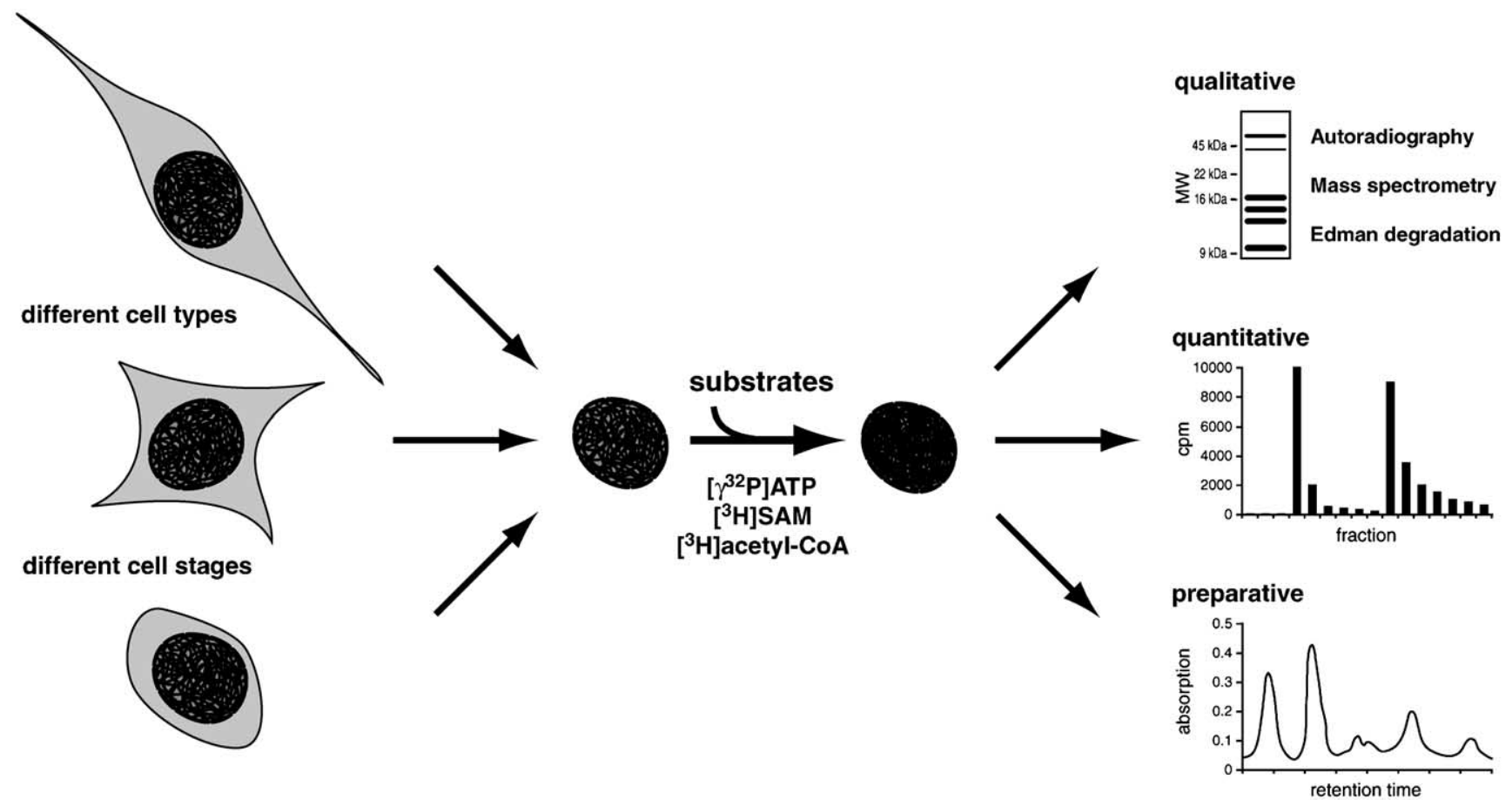

Fig. 1. Schematic flow diagram of in nucleo assays. For details, see text. $\left[\gamma^{32} \mathrm{P}\right] \mathrm{ATP}$, adenosine $5^{\prime}-\left[\gamma-{ }^{32} \mathrm{P}\right] \mathrm{triphosphate}$; $\left[{ }^{3} \mathrm{H}\right] \mathrm{acetyl}-\mathrm{CoA}$, [acetyl- $\left.{ }^{3} \mathrm{H}\right]$ acetyl-coenzyme A; $\left[{ }^{3} \mathrm{H}\right] \mathrm{SAM}, S$-adenosyl-L-[methyl- $\left.{ }^{3} \mathrm{H}\right]$ methionine. 

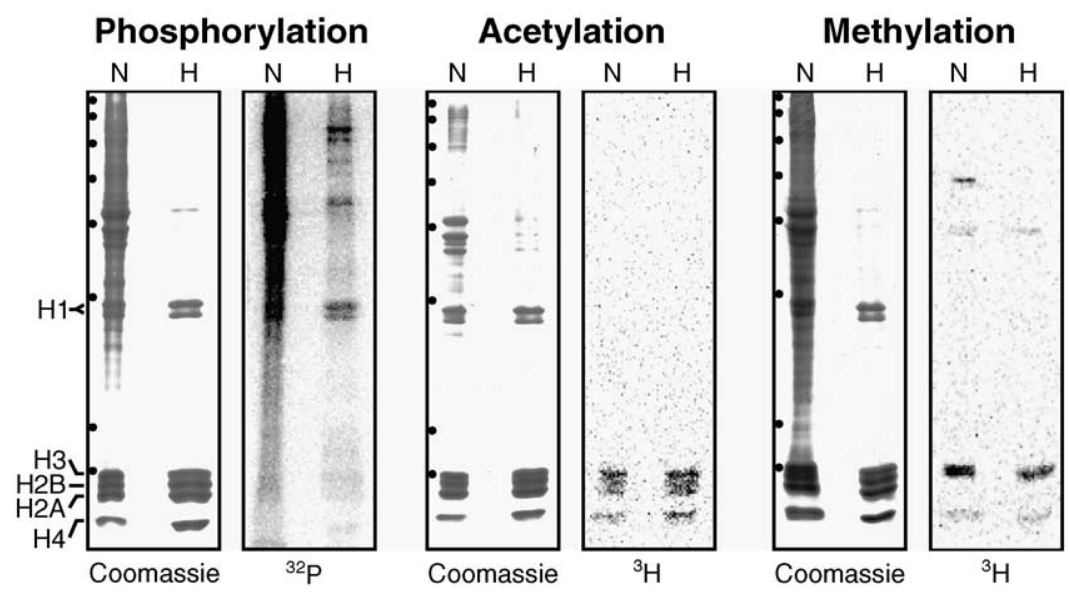

Fig. 2. In nucleo analysis of phosphorylation, acetylation, and methylation of HeLa cells. $5 \times 10^{6}$ nuclei each of asynchronously growing HeLa cells were incubated with radioactive substrates $\left[\gamma-{ }^{32} \mathrm{P}\right] \mathrm{ATP},\left[{ }^{3} \mathrm{H}\right]$ acetyl-CoA, or $\left[{ }^{3} \mathrm{H}\right] \mathrm{SAM}$, respectively. Reactions were split in half and either stopped directly by adding boiling Laemmli loading buffer (N, nuclear sample) or basic proteins were acid extracted from nuclei, precipitated with TCA and resuspended in boiling Laemmli loading buffer (A, acid extract). One-tenth of each fraction was loaded onto 15\% SDS-PAGE gels. Gels were stained with Coomassie Blue. Autoradiography was performed using a Phosphoimager. Dots indicate molecular weight markers; from the top: 250, 148, 98, $64,50,36,22$, and $16 \mathrm{kDa}$.

DMSO); $1 \mu \mathrm{g} / \mathrm{ml}$ peptstatin A (Roche; stock, $1 \mathrm{mg} / \mathrm{ml}$ in ethanol); $1 \mu \mathrm{g} / \mathrm{ml}$ leupeptin (Roche; stock, $1 \mathrm{mg} / \mathrm{ml}$ in $\mathrm{H}_{2} \mathrm{O}$ ); $2 \mu \mathrm{g} / \mathrm{ml}$ aprotinin (Roche; stock, $10 \mathrm{mg} / \mathrm{ml}$ in $\mathrm{H}_{2} \mathrm{O}$ ); $0.5 \mathrm{mM}$ PMSF (SIGMA; stock, $100 \mathrm{mM}$ in ethanol); $2 \mathrm{mM}$ benzamidine- $\mathrm{HCl}$ (SIGMA; stock, $1 \mathrm{M}$ in $\mathrm{H}_{2} \mathrm{O}$ ); store all inhibitor stock solutions at $-20^{\circ} \mathrm{C}$.

Phosphatase inhibitors: we routinely use $1 \mu \mathrm{M}$ microcystin LR (Calbiochem; stock, $1 \mathrm{mM}$ in DMSO; store at $-20^{\circ} \mathrm{C}$ ) in phosphorylation in nucleo experiments. The following buffer additions, alone or in combination, might also be useful to inhibit serine/threonine phosphatases in these assays: $5 \mathrm{mM} \mathrm{Na}_{4} \mathrm{P}_{2} \mathrm{O}_{7}$ (Sodiumpyrophosphate); $50 \mathrm{mM} \mathrm{NaF} ; 10 \mathrm{mM} \beta$-glyerophosphate.

Deacetylase inhibitor: $400 \mathrm{nM}$ trichostatin A (SIGMA; stock, $1 \mathrm{mM}$ in DMSO; store at $-20^{\circ} \mathrm{C}$ ).

\subsubsection{Yeast nuclei}

\subsubsection{Reagents}

SP buffer: $20 \mathrm{mM}$ PIPES (pH 6.3), $1.1 \mathrm{M}$ sorbitol.

SPI buffer: SP buffer, protease inhibitors.

FPMI buffer: $20 \mathrm{mM}$ PIPES (pH 6.3), $1 \mathrm{mM} \mathrm{MgCl}_{2}$, $18 \%$ Ficoll, protease inhibitors.

NP buffer: $20 \mathrm{mM}$ Tris- $\mathrm{HCl}(\mathrm{pH}$ 7.4), $340 \mathrm{mM}$ sucrose, $50 \mathrm{mM} \mathrm{KCl}, 5 \mathrm{mM} \mathrm{MgCl}_{2}$, protease inhibitors.

CP buffer: $20 \mathrm{mM}$ Tris- $\mathrm{HCl}$ ( $\mathrm{pH}$ 7.4), $1.7 \mathrm{M}$ sucrose, $50 \mathrm{mM} \mathrm{KCl}, 5 \mathrm{mM} \mathrm{MgCl}$, protease inhibitors.

\subsubsection{Methods}

1. Grow yeast cells to desired density in appropriate growth media i.e., YPD. Routinely, we have used cells at early log phase (corresponding to $\approx 1 \times 10^{7}$ cells $/ \mathrm{ml}$ ), but cells at other stages of growth can also be used.
2. Harvest cells by centrifugation at RT, $5 \mathrm{~min}, 5000 \mathrm{~g}$. Wash cells once with water and once with SP buffer.

3. Resuspend cells in SP buffer at $1-3 \times 10^{8}$ cells $/ \mathrm{ml}$. Add 2-mercaptoethanol to $14 \mathrm{mM}$ final concentration. Then take an aliquot of $10 \mu \mathrm{l}$ cell suspension as a control for spheroplasting.

4. Add 2-5 $\mu \mathrm{g}$ Zymolase-100T (ICN) per milliliter of cell suspension. Incubated at $30^{\circ} \mathrm{C}$ with gentle agitation (ca. 100-120 rpm) until spheroplasting is 80 $90 \%$ complete (usually about $30 \mathrm{~min}$ ). Monitor progression of reaction at 15 min intervals by mixing $10 \mu \mathrm{L}$ of cell suspension with $1 \mathrm{ml} 1 \%$ SDS. The decrease in $\mathrm{OD}_{600 \mathrm{~nm}}$ reading indicates the degree of spheroplasting (i.e., 0.1 before the addition of zymolase to 0.01 after incubation indicates $90 \%$ spheroplasting). Alternatively the percentage of cells that burst upon addition of water can be checked under a microscope.

5. Collect spheroplasts by centrifugation, $4{ }^{\circ} \mathrm{C}$, $5 \mathrm{~min}, 4000 \mathrm{~g}$. Wash yeast spheroplasts once in cold SPI buffer (at ca. $1-3 \times 10^{9}$ cells $/ \mathrm{ml}$ ). Keep spheroplasts on ice from hereon.

6. Resuspend spheroplasts gentle as a slurry in the residual amount of SPI buffer, then add FPMI buffer to $0.5-1 \times 10^{9}$ cells $\left./ \mathrm{ml}\right)$. Transfer the suspension to a pre-cooled Dounce homogenizer (Wheaton, pestle B) and disrupt the spheroplasts with 20-30 strikes.

7. Transfer suspension to a pre-chilled centrifuge tube and leave on ice for $10 \mathrm{~min}$. Remove debris by centrifugation, $4{ }^{\circ} \mathrm{C}, 10 \mathrm{~min}, 3000 \mathrm{~g}$. Collect supernatant without disturbing the pellet and transfer to a pre-chilled ultra centrifuge tube.

8. Pellet nuclei by centrifugation, $4^{\circ} \mathrm{C}, 30 \mathrm{~min}$, $50,000 g$. Resuspend nuclei in NP buffer (at ca. 1$3 \times 10^{9}$ cells $/ \mathrm{ml}$ ). We found that higher yields of 
nuclei can be achieved by re-extracting the pellet of step 7 with the supernatant of the high-speed centrifugation (Dounce homogenization).

9. Overlay nuclei suspension on $2 \mathrm{ml}$ of $\mathrm{CP}$ buffer and centrifuge $4{ }^{\circ} \mathrm{C}, 30 \mathrm{~min}, 30,000 \mathrm{~g}$.

10. Re-suspend nuclei in NP buffer (at ca. $1-3 \times 10^{9}$ cells $/ \mathrm{ml}$ ). Use nuclei immediately or freeze in liquid $\mathrm{N}_{2}$ and store at $-80^{\circ} \mathrm{C}$ until further use.

Notes: We routinely grow $1-21$ cultures to obtain a significant number of yeast cells for the preparation of nuclei according to this protocol. As an alternative to zymolase, yeast lytic enzyme (ICN) at $5 \mathrm{mg} / \mathrm{ml}$ can be used for spheroplasting (step 4).

\subsubsection{Nuclei from mammalian cell lines}

2.1.2.1. Reagents

Buffer I: $10 \mathrm{mM}$ Hepes-NaOH (pH 7.9), $10 \mathrm{mM}$ $\mathrm{KCl}, \quad 1.5 \mathrm{mM} \mathrm{MgCl}_{2}, \quad 0.5 \mathrm{mM}$ DTT, protease inhibitors.

Buffer II: Buffer I, 0.1\% (v/v) Nonidet P-40, protease inhibitors.

Buffer III: $20 \mathrm{mM}$ Hepes-NaOH (pH 7.9), $50 \mathrm{mM}$ $\mathrm{KCl}, \quad 1.5 \mathrm{mM} \quad \mathrm{MgCl}_{2}, \quad 0.5 \mathrm{mM}$ DTT, $0.2 \mathrm{mM}$ EDTA, 20\% (v/v) glycerol, protease inhibitors.

\subsubsection{Methods}

1. Harvest suspension culture cells by centrifugation $\left(4{ }^{\circ} \mathrm{C}, 10 \mathrm{~min}, 600 \mathrm{~g}\right)$; scrape adherent cells into PBS. Wash cells twice with cold PBS.

2 . Wash cells twice in buffer $\mathrm{I}\left(\approx 1 \times 10^{7}\right.$ cells $/ \mathrm{ml}$; centrifuge, $4^{\circ} \mathrm{C}, 10 \mathrm{~min}, 600 \mathrm{~g}$ ).

3. Re-suspend swollen cells in buffer II at $\approx 1 \times 10^{8}$ cells/ $\mathrm{ml}$. Incubated on ice for $10 \mathrm{~min}$ with intermittent mixing.

4. Collect nuclei by centrifugation $\left(4^{\circ} \mathrm{C}, 10 \mathrm{~min}, 600 \mathrm{~g}\right)$. Wash nuclei once in buffer III.

5. Re-suspend nuclei in buffer III (at $\approx 1 \times 10^{8}$ cells $/ \mathrm{ml}$ ). Use nuclei immediately or freeze in liquid $\mathrm{N}_{2}$ and store at $-80{ }^{\circ} \mathrm{C}$ until further use.

Notes: Nuclei prepared by other methods, for example, the classical protocol according to Dignam et al. [16] can also be used. However, different preparation methods, may lead to varying results and labeling efficiencies from the same batch of cells since enzymes can be inactivated or washed out of the nuclei under conditions of high $(>500 \mathrm{mM}$ total ionic strength) or low ( $<10 \mathrm{mM}$ total ionic strength) salt. Optionally, nuclei can be further purified by centrifugation through a sucrose cushion. Resuspend nuclei (at $\approx 1 \times 10^{7}$ cells $/ \mathrm{ml}$ ) in buffer I containing $0.25 \mathrm{M}$ sucrose and overlay on a cushion of $2 \mathrm{ml}$ buffer I containing $2.3 \mathrm{M}$ sucrose. Pellet nuclei through the density cushion by centrifugation, $4{ }^{\circ} \mathrm{C}, 60 \mathrm{~min}$, $1,00,000 \mathrm{~g}$. Proceed according to step 4. An alternative formulation of buffer III contains $0.25 \mathrm{M}$ sucrose instead of $20 \%(\mathrm{v} / \mathrm{v})$ glycerol.

\subsection{In nucleo labeling reactions}

The number of nuclei used in the provided protocols is for mammalian cell lines. When nuclei form other cellular sources are to be used, adjust the number of nuclei according to the nuclear content of these cells (i.e., routinely we use $10 \times$ more nuclei from yeast cells in our in nucleo reactions when comparing modifying activities from yeast and human cells).

\subsubsection{Phosphorylation}

\subsubsection{Reagents}

NK buffer: $10 \mathrm{mM}$ Tris- $\mathrm{HCl}(\mathrm{pH}$ 7.5), $250 \mathrm{mM}$ sucrose, $35 \mathrm{mM} \mathrm{KCl}, 35 \mathrm{mM} \mathrm{NaCl}, 5 \mathrm{mM} \mathrm{MgCl}_{2}$, $1 \mathrm{mM}$ DTT. Store frozen in aliquots at $-20^{\circ} \mathrm{C}$. Add protease and phosphatase inhibitors immediately before use. We routinely find that $1 \mathrm{mM}$ PMSF is sufficient to inhibit the degradation of histones during the short incubation times applied.

10X ATP mix: $100 \mu \mathrm{M}$ ATP, $1 \mu \mathrm{Ci}$ adenosine-5'$\left[\gamma-{ }^{32} \mathrm{P}\right]$ triphosphate $/ \mu \mathrm{l} \quad\left(\left[\gamma-{ }^{32} \mathrm{P}\right] \mathrm{ATP} ; 3000 \mathrm{Ci} / \mathrm{mmol}\right.$; ICN or Amersham). Aliquots of $100 \mu \mathrm{M}$ ATP can be stored frozen at $-20{ }^{\circ} \mathrm{C}$ for at least 6 month.

\subsubsection{Methods}

1. Aliquot $5 \times 10^{6}$ nuclei into $1.5 \mathrm{ml}$ microcentrifuge tubes and centrifuge briefly, $4{ }^{\circ} \mathrm{C}, 500 \mathrm{~g}$ (swinging bucket rotor recommended). Resuspend nuclei in $45 \mu \mathrm{l}$ of cold NK buffer. Transfer tubes to RT for ca. $5 \mathrm{~min}$.

2. Add $5 \mu \mathrm{l}$ of $10 \mathrm{X}$ ATP mix to start the reaction. Incubate at RT for 5-30 min (longer incubation times usually do not result in more efficient labeling). Gently agitate intermittently to keep nuclei in suspension.

3. Wash nuclei once with NK buffer and terminate reaction by adding boiling Laemmli SDS loading buffer or by resuspending nuclei in $0.4 \mathrm{~N} \mathrm{H}_{2} \mathrm{SO}_{4}$ and proceed with histone extraction (see below).

\subsubsection{Acetylation}

\subsubsection{Reagents}

NA buffer: $50 \mathrm{mM}$ Tris- $\mathrm{HCl}$ (pH 8.0), $50 \mathrm{mM} \mathrm{NaCl}$, $1 \mathrm{mM}$ EDTA, $0.5 \mathrm{mM}$ DTT, $10 \%$ (w/v) sucrose, protease inhibitors, deacetylase inhibitors. [Acetyl $\left.-{ }^{3} \mathrm{H}\right] \mathrm{ac}-$ etyl-coenzyme A $\left(\left[{ }^{3} \mathrm{H}\right]\right.$ acetyl-CoA; $\quad 6.0 \mathrm{Ci} / \mathrm{mmol}$; Amersham Pharmacia).

\subsubsection{Methods}

1. Aliquot $5 \times 10^{6}$ nuclei into $1.5 \mathrm{ml}$ microcentrifuge tubes and centrifuge briefly, $4{ }^{\circ} \mathrm{C}, 500 \mathrm{~g}$ (swinging bucket rotor recommended). Resuspend nuclei in $20 \mu \mathrm{l}$ of cold NA buffer. Transfer tubes to RT for ca. $5 \mathrm{~min}$. 
2. Add $5 \mu \mathrm{l}$ of $5 \mu \mathrm{M}\left[{ }^{3} \mathrm{H}\right]$ acetyl-CoA in NA buffer to start the reaction. Incubate at $30^{\circ} \mathrm{C}$ for $60 \mathrm{~min}$. Gently agitate intermittently to keep nuclei in suspension.

3. Wash nuclei once with NA buffer and terminate reaction by adding boiling Laemmli SDS loading buffer or by resuspending nuclei in $0.4 \mathrm{~N} \mathrm{H}_{2} \mathrm{SO}_{4}$ and proceed with histone extraction (see below).

\subsubsection{Methylation}

\subsubsection{Reagents}

NM buffer: $50 \mathrm{mM}$ Tris- $\mathrm{HCl}$ ( $\mathrm{pH} 8.0$ ), $50 \mathrm{mM} \mathrm{NaCl}$, $10 \mathrm{mM} \mathrm{MgCl} 2,0.5 \mathrm{mM}$ DTT, $10 \%(\mathrm{w} / \mathrm{v})$ sucrose, protease inhibitors. $S$-adenosyl-L-[methyl- $\left.{ }^{3} \mathrm{H}\right]$ methionine $\left(\left[{ }^{3} \mathrm{H}\right] \mathrm{SAM} ; 10.2 \mathrm{Ci} / \mathrm{mmol}\right.$; NEN Life Sciences Products).

\subsubsection{Methods}

1. Aliquot $5 \times 10^{6}$ nuclei into $1.5 \mathrm{ml}$ microcentrifuge tubes and centrifuge briefly, $4{ }^{\circ} \mathrm{C}, 500 \mathrm{~g}$ (swinging bucket rotor recommended). Resuspend nuclei in $20 \mu \mathrm{l}$ of cold NA buffer. Transfer tubes to RT for ca. $5 \mathrm{~min}$.

2. Add $5 \mu \mathrm{l}$ of $5 \mu \mathrm{M} S$-adenosyl-L-[methyl $\left.{ }^{3} \mathrm{H}\right]$ methionine in NM buffer to start the reaction. Incubate at $30^{\circ} \mathrm{C}$ for $60 \mathrm{~min}$. Gently agitate intermittently to keep nuclei in suspension.

3. Wash nuclei once with NM buffer and terminate reaction by adding boiling Laemmli SDS loading buffer or by resuspending nuclei in $0.4 \mathrm{~N} \mathrm{H}_{2} \mathrm{SO}_{4}$ and proceed with histone extraction (see below).

Notes: Boiling nuclei directly in Laemmli SDS loading buffer (increased boiling times ( $>5 \mathrm{~min}$ ) are recommended) often results in very viscous solutions that cannot be loaded onto SDS-PAGE gels. Shear genomic DNA by pushing solution $20 \times$ through a $27 \mathrm{~g}$ needle.

\subsection{Analysis and acid extraction of histones}

\subsubsection{Reagents}

$0.4 \mathrm{NH}_{2} \mathrm{SO}_{4}$ (concentrated sulfuric acid is $18 \mathrm{M}$, $36 \mathrm{~N}) .100 \%(\mathrm{w} / \mathrm{v})$ TCA: dissolve $100 \mathrm{~g}$ trichloroacidic acid into a total volume of $100 \mathrm{ml}$ water. Store at $\mathrm{RT}$ in the dark ( $<6$ month). Ice cold acetone (keep at $\left.-20^{\circ} \mathrm{C}\right)$. Ice cold acidified acetone: $0.1 \%(\mathrm{v} / \mathrm{v}) \mathrm{HCl}$ in acetone (keep at $-20^{\circ} \mathrm{C}$ ).

\subsubsection{Methods}

1. Extract nuclei by re-suspending washed pellet well in $0.4 \mathrm{~N} \mathrm{H}_{2} \mathrm{SO}_{4}$ (final) at $0.5-1 \times 10^{8} / \mathrm{ml}$. Shake gently for at least $2 \mathrm{~h}$ (to overnight) at $4{ }^{\circ} \mathrm{C}$.

2. Collect the acid-soluble supernatant after centrifugation, $4{ }^{\circ} \mathrm{C}, 10 \mathrm{~min}, 5000 \mathrm{~g}$. Acid-insoluble pellets are usually discarded because they contain little histone.

3. Precipitate acid soluble proteins by adding $100 \%$ (v/v) trichloroacetic acid (TCA) to $20 \%(\mathrm{v} / \mathrm{v})$ final. Mix well and incubate on ice for $60 \mathrm{~min}$.
4. Collect precipitates by centrifugation, $4{ }^{\circ} \mathrm{C}, 15 \mathrm{~min}$, $15,000 g$.

5. Wash precipitates twice with acidified acetone and twice with acetone. Air dry pellet completely.

6. Re-suspend pellet in boiling water or directly in boiling Laemmli SDS loading buffer. As a rule of thumb, histones extracted from $\approx 0.5-1 \times 10^{6}$ nuclei are corresponding to the amount of histones clearly visible on a SDS-PAGE gel stained with Coomassie Blue R-250.

Notes: When working with yeast nuclei, wash nuclei three times with $10 \mathrm{mM}$ Tris- $\mathrm{HCl}(\mathrm{pH} 8.0), 75 \mathrm{mM}$ $\mathrm{NaCl}$, protease and phosphatase inhibitors (at ca. $5 \times 10^{8}$ cells $/ \mathrm{ml}$ ). Then resuspend nuclei in $10 \mathrm{mM}$ Tris- $\mathrm{HCl}$ ( $\mathrm{pH} 8.0), 400 \mathrm{mM} \mathrm{NaCl}$, protease and phosphatase inhibitors (at ca. $1 \times 10^{9}$ cells $/ \mathrm{ml}$ ). Gradually add $4 \mathrm{~N} \mathrm{H}_{2} \mathrm{SO}_{4}$ to a final concentration of $0.4 \mathrm{~N}$. Proceed with histone extraction as described.

Alternatively to the precipitation of total protein with TCA, core histones (H2A, H2B, H3, and H4) can be precipitated more selectively by the addition of perchloric acid (PCA) to $5.4 \%(\mathrm{v} / \mathrm{v})$ final to the acid soluble fraction (step 2). Linker histones of the $\mathrm{H} 1$ type and basic HMG proteins are soluble under these conditions and will therefore be separated from core histones. After centrifugation and recovery of the precipitated core histones, histone $\mathrm{H} 1$, and $\mathrm{HMG}$ proteins can be collected after precipitation with $20 \%(\mathrm{v} / \mathrm{v})$ TCA.

\section{Concluding remarks}

In nucleo experiments in essence similar to the procedures described here were used frequently during the initial discovery of histone modifications [9-12]. Over the years these simple methods have been more and more overlooked and were substituted by cellular labeling experiments. Neither, ATP, nor Acetyl-CoA, nor SAM is cell-permeable. Ortho-phosphate, acetate, leucine, or methyl-methionine $[17,18]$ are taken up by various cell types (yeast cells have to be spheroplasted to achieve good uptake) and are intracellularly converted to ATP, Acetyl-CoA, and SAM, respectively. However, labeling efficiencies of cellular labeling reactions are often rather low. In nucleo reactions can offer a very effective and cost saving alternative as nuclei in the described procedures can be highly concentrated and are easily penetrated by the substrates ATP, Acetyl-CoA, and SAM [13].

A so far very little exploited area of in nucleo assays concerns the modification of nuclear proteins other than histones by phosphorylation, acetylation, or methylation. Obviously, other - yet unknown - proteins can become modified by the same or different enzymatic activities that are targeting histones in these reactions (see Fig. 2). In addition, the study of post-translational 
modification(s) of defined but less abundant nuclear proteins should be accessible in in nucleo experiments. We have just started to exploit this area by using nuclei from cells that have been engineered to overexpress (for example, by transfection) defined factors that contain immuno-affinity tags (such as FLAG- and/or HA-tags) for ready identification and purification.

\section{Acknowledgments}

I like to thank C. David Allis and all current and past members of his laboratory for input and support. Especially, I am grateful to Drs. Craig Mizzen, Arthur Hsu, and Brian Strahl for initial protocol development. W.F. is a Robert Black fellow of the Damon Runyon Cancer Research Foundation.

\section{References}

[1] M. Iizuka, M.M. Smith, Curr. Opin. Genet. Dev. 13 (2003) 154 160.
[2] W. Fischle, Y. Wang, C.D. Allis, Curr. Opin. Cell. Biol. 15 (2003) $172-183$.

[3] K.E. van Holde, Chromatin, Springer, New York, 1988.

[4] S.C. Galasinski, K.A. Resing, N.G. Ahn, Methods 31 (2003) 3-11.

[5] T. Bonaldi, J.T. Regula, A. Imhof, Methods Enzymol. 377 (2004) 111-130.

[6] M. Bustin, R.C. Robinson, F.K. Friedman, Methods Enzymol. 376 (2004) 209-220.

[7] P. Cheung, Methods Enzymol. 376 (2004) 221-234.

[8] W. An, R.G. Roeder, Methods Enzymol. 377 (2004) 460-474.

[9] V.G. Allfrey, R. Faulkner, A.E. Mirsky, Proc. Natl. Acad. Sci. USA 51 (1964) 786-794.

[10] K. Murray, Biochemistry 3 (1964) 10-16.

[11] M.G. Ord, L.A. Stocken, Biochem. J. 98 (1966) 888-893.

[12] D.M.P. Phillips, Biochem. J. 87 (1963) 258-265.

[13] B.D. Strahl, R. Ohba, R.G. Cook, C.D. Allis, Proc. Natl. Acad. Sci. USA 96 (1999) 14967-15572.

[14] U. Certa, G. von Ehrenstein, Anal. Biochem. 118 (1982) 147154.

[15] J.S. Bonifacino, M. Dasso, J.B. Harford, J. Lippincott-Schwartz, K.M. Yamada, Current Protocols in Cell Biology, John Wiley \& Sons, New York, 1998.

[16] J.D. Dignam, P.L. Martin, B.S. Shastry, R.G. Roeder, Methods Enzymol. 101 (1983) 582-598.

[17] R. Camato, R.M. Tanguay, EMBO J. 1 (1982) 1529-1532.

[18] J.H. Waterborg, J. Biol. Chem. 268 (1993) 4918-4921. 